\title{
Effect of variety and dehulling on nutritional value of white lupin seeds for growing pigs*
}

\author{
Marianna Flis ${ }^{1}$, W. Sobotka ${ }^{1}$ and Z. Zduńczyk ${ }^{2}$
}

\author{
${ }^{I}$ Institute of Animal Nutrition and Feed Management, \\ Olsztyn University of Agriculture and Technology \\ Oczapowskiego 5, 10-718 Olsztyn, Poland \\ ${ }^{2}$ Institute of Animal Reproduction and Food Research, Polish Academy of Sciences, \\ Division of Food Science \\ Tuwima 10, 10-7l8 Olsztyn, Poland
}

(Received 28 March 1997; accepted 24 October 1997)

\section{ABSTRACT}

The nutritional value of three Polish varieties of white lupin: whole seeds of an older variety, Wat, a newer variety, Hetman, as well as whole or dehulled seeds of the newest variety, Bardo, was determined in a 36-day growth experiment (Experiment 1 ) on 25 barrows (30-56 kg BW). Twenty per cent whole seeds or $16.5 \%$ dehulled seeds were added to the diet at the expense of the soyabean oilmeal which was decreased from $19 \%$ in the control diet to $6-9 \%$ in the experimental diets.

In comparison with the control group, daily weight gains and feed utilization were significantly poorer in the pigs fed the diet containing Wat seeds $(0.106 \%$ alkaloids in DM), while performance of pigs fed Hetman or Bardo lupin $(0.035 \%$ and $0.052 \%$ alkaloids, respectively) was only insignificantly worse. In pigs fed dehulled seeds, fattening performance was the same as in the control group.

In the second experiment (2), nutrients digestibility of the three lupin varieties and dehulled Bardo lupin seeds was determined by difference method. No significant differences in the digestibility of crude protein, crude fibre or $\mathrm{N}$-free extractives were found among the evaluated varieties. Digestibility of energy was the greatest in Hetman seeds. Dehulling the seeds increased digestibility of energy from 80.8 to $86.4 \%$ ( $P<0.01)$. Dehulled seeds contained more metabolizable energy $(16.0 \mathrm{vs.}$ $14.1 \mathrm{MJ} / \mathrm{kg}$ ) and digestible protein ( $371 \mathrm{vs.} 295 \mathrm{~g} / \mathrm{kg}$ ), while less crude fibre (42 vs. $129 \mathrm{~g} / \mathrm{kg}$ ) than whole seeds.

KEY WORDS : white lupin, dehulling, digestibility, performance, pigs

\footnotetext{
* Supported by the State Committee for Scientific Research, Grant No 5 S305 507
} 


\section{INTRODUCTION}

The nutritional value of lupin for pigs is determined mainly by its alkaloid content. The studies of Buraczewska et al. (1993) have shown that the dietary alkaloid level tolerated by young pigs depends on the species and variety of lupin and ranges from 90 to $455 \mathrm{mg}$ per $\mathrm{kg}$ of diet. These authors also found that pigs are more sensitive to the alkaloids of white lupin than those of narrow-leafed and yellow lupin. It is recommended to use only up to $10-15 \%$ of low-alkaloid varieties of white lupin in the diet so as not to decrease the palatability of diet, daily weight gains and feed utilization in fattening pigs (Bourdon et al. 1980; King, 1981; Brand et al., 1995; Zettl et al., 1995).

In Poland, less white lupin is cultivated than other species. For many years only one low-alkaloid variety, Wat, was grown. It has an alkaloid content of about $0.1-0.13 \%$ and a low nutritional value for pigs (Fuchs et al., 1983; Flis et al., 1989). Newer varieties (Hetman, Bardo) have lower alkaloid contents - about 0.04-0.08\% (Buraczewska et al., 1993; Zduńczyk et al., 1996) and are more suitable for use in pig feeding. The nutritional value of the Hetman variety for young barrows as assessed by Gdala et al. (1996) was only slightly (and insignificantly) less than that of yellow and narrow-leafed lupin.

Another component of lupin seeds affecting their nutritional value for pigs, particularly young ones, is their substantial fibre content (Eggum et al., 1993). For this reason, dehulling may be a good method of decreasing the amount of components with low nutritional value for pigs.

The objective of this study was to determine the nutritional value of three Polish varieties of white lupin (Wat, Hetman, Bardo) and dehulled lupin seeds (Bardo) in pig nutrition.

\section{MATERIAL AND METHODS}

The nutritional value of three varieties of lupin and dehulled seeds was assessed in two experiments on the basis of : daily body weight gain, feed utilization and nutrient digestibility in pigs fed diets containing the studied varieties and forms of seeds (Experiment 1); nutrient digestibility of whole and dehulled seeds, determined by a difference method, and digestible energy (DE), metabolizable energy (ME) and digestible crude protein (DCP) contents in seeds (Experiment 2).

The seeds were dehulled using a method developed at the Institute of Agricultural and Machinery and Equipment, Olsztyn University of Agriculture and Technology. Dehulling efficiency was $70 \%$. 


\section{Animals and diets}

Experiment 1 was conducted on 24 barrows (from Polish Large White sows and Duroc boars), 5 per group, housed individually in metabolic cages. Isonitrogenous diets balanced, according to the Nutrient Requirements of Pigs (1993), were used (Table 1). The protein component of the control group diet was soyabean oilmeal (group C).

TABLE 1

Composition and nutritive value of diets (Experiment 1)

\begin{tabular}{|c|c|c|c|c|c|}
\hline \multirow[t]{2}{*}{ Indices } & \multicolumn{5}{|c|}{ Groups $^{1}$} \\
\hline & $\mathrm{C}$ & W & $\mathbf{H}$ & B & $\mathrm{dB}$ \\
\hline \multicolumn{6}{|l|}{ Ingredients, $\%$} \\
\hline barley & 42.41 & 32.21 & 34.67 & 34.20 & 38.68 \\
\hline wheat & 35.0 & 35.0 & 35.0 & 35.0 & 35.0 \\
\hline soyabean meal (SBM) & 19.0 & 9.0 & 6.5 & 7.0 & 6.0 \\
\hline lupin & - & 20.0 & 20.0 & 20.0 & 16.5 \\
\hline minerals $^{2}$ & 2.4 & 2.5 & 2.5 & 2.5 & 2.5 \\
\hline mineral-witamin premix & 1.0 & 1.0 & 1.0 & 1.0 & 1.0 \\
\hline L-lysine HCL & 0.13 & 0.20 & 0.23 & 0.21 & 0.23 \\
\hline DL-methionine & 0.06 & 0.09 & 0.10 & 0.09 & 0.09 \\
\hline \multicolumn{6}{|l|}{ Chemical composition, $\%$} \\
\hline dry matter & 87.44 & 87.60 & 87.59 & 87.45 & 87.60 \\
\hline crude protein & 17.56 & 17.45 & 17.63 & 17.56 & 17.94 \\
\hline ether extract & 2.94 & 4.43 & 4.41 & 4.20 & 4.19 \\
\hline crude fibre & 4.47 & 6.15 & 5.70 & 5.89 & 3.88 \\
\hline alkaloids $^{3}$ & - & 0.019 & 0.006 & 0.009 & nd \\
\hline gross energy, $\mathrm{MJ} / \mathrm{kg}$ & 16.39 & 16.64 & 16.82 & 16.56 & 16.65 \\
\hline \multicolumn{6}{|l|}{ Nutrient contents, $\mathrm{g} / \mathrm{kg}$} \\
\hline digestible crude protein & 146.3 & 136.3 & 143.7 & $\mathrm{I} 40.3$ & 146.7 \\
\hline lysine $e^{3}$ & 9.02 & 9.44 & 9.36 & 9.30 & 9.43 \\
\hline methionine ${ }^{3}$ & 3.09 & 3.16 & 3.14 & 3.12 & 3.12 \\
\hline threonine ${ }^{3}$ & 6.23 & 6.42 & 6.33 & 6.23 & 6.19 \\
\hline $\mathrm{Ca}$ & 7.6 & 7.7 & 7.6 & 7.6 & 7.6 \\
\hline$P$ digestible & 2.9 & 3.1 & 3.1 & 3.1 & 3.1 \\
\hline metabolizable energy, $\mathrm{MJ} / \mathrm{kg}$ & 12.87 & 12.50 & 12.90 & 12.70 & 13.05 \\
\hline \multicolumn{6}{|l|}{$\begin{array}{l}\text { SBM crude protein } \\
\text { substitution by lupin }\end{array}$} \\
\hline protein, $\%$ & 0 & 67 & 77 & 75 & 76 \\
\hline
\end{tabular}

main protein concentrate in the diet: soyabean meal (S) or lupin seeds v. Wat (W), v. Hetman (H), v. (Bardo (B), dehulled seeds v. Bardo (dB)

${ }^{2}$ dicalcium phosphate $1.2 \%$, limestone $0.9-1.0 \%$, salt $0.3 \%$

${ }^{3}$ calculated from values measured in the feed ingredients (Table 3) 
In the experimental diets, $66-77 \%$ of the soyabean protein was replaced by lupin: Wat (group W), Hetman (H), and Bardo (B) in amounts of $20 \%$ of the diet, and by dehulled Bardo seeds (dB) in an amount of $16.5 \%$. The adaptation period to the experimental diets after switching from the control feed lasted 13 days. The growth experiments were conducted for the subsequent 36 days and ended by determining the nutrients digestibility and nitrogen balance.

Experiment 2 was carried out on the same barrows after completion of Experiment 1. Nutrients and energy digestibility of Wat, Hetman, Bardo and dehulled Bardo seeds were determined by a difference method. The basic diet (Table 2) was fed to one group, three groups were fed diets containing the basic diet $(80 \%)$ and the studied lupin variety $(20 \%)$ : Wat, Hetman, Bardo; the last group received dehulled Bardo seeds $(16.5 \%)$ and the basic diet $(83.5 \%)$. The adaptation period lasted 9 days. The weight of the animals at the beginning of the actual experimental period was about $61 \mathrm{~kg}$ (in group W, about $50 \mathrm{~kg}$ ).

The lupin seeds and cereals used in both experiments were from the same lots. The animals were fed according to Polish standards (1993), twice a day at 7 and $15 \mathrm{~h}$, in moistened form (feed : water as 1:1).

Faeces (Experiments 1, and 2) and urine (Experiment 1) collections were conducted over 5-day periods. Two average samples of about $10 \%$ were taken from the daily faeces collection. One preserved with sulphuric acid was used for $\mathrm{N}$ determination, the other was dried and used for nutrients and energy

TABLE 2

Composition of basal diet (BD) (Experiment 2)

\begin{tabular}{lc}
\hline Indices & \\
\hline Ingredients, \% & 69.3 \\
barley & 20.0 \\
wheat & 7.0 \\
soyabean meal & 1.2 \\
dicalcium phosphate & 1.0 \\
limestone & 0.3 \\
salt & 1.0 \\
mineral-vitamin premix & 0.2 \\
L-lysine HCL & \\
Chemical composition, \% & 86.40 \\
dry matter & 4.44 \\
crude ash & 13.25 \\
crude protein & 2.73 \\
ether extract & 4.57 \\
crude fibre & 61.05 \\
N-free extractives & 15.94 \\
Gross energy, MJ/kg & \\
\hline
\end{tabular}


determination. Urine was collected in containers with sulphuric acid in an amount lowering $\mathrm{pH}$ under 2.

\section{Chemical analysis}

The basic composition of feeds and faeces, and urinary $\mathrm{N}$ was determined using conventional methods, ether extract (EE) was determined following hydrolysis with $\mathrm{HCl}$. NDF and ADF contents in feeds were determined according to Van Soest and Wine (1967) using a Fibertec apparatus. Soluble sugars were assayed according to Jacórzyński (1986), starch was determined (only in protein feeds) by an enzymatic method (Keppler and Decker, 1970). Total alkaloids (TA) were determined by a gravimetric method according to Wysocka et al. (1989). Total energy in feeds and in dried faeces was determined by combustion in an adiabatic bomb. The ME contents in the feed mixtures (Experiment 1) and in lupin seeds (Experiment 2) were computed on the basis of chemical composition and digestibility coefficients using the formula of Hoffmann and Schiemann (1980), with adjustments for the content of sugars and bacterially fermented structural polysaccharides (Müller and Kirchgessner, 1983). The amino acid composition of protein was determined using a Czech AAAT 339M amino acid analyzer. The essential amino acid index was computed according to Oser, using our own modification (Flis, 1993) in which we replace the amino acid composition of egg protein with the composition of the ,ideal" protein for pigs (Wang and Fuller, 1990). The modified essential amino acid index computed this way is denoted M EAAI, and the limiting amino acid is denoted as M CS.

\section{Statistical analysis}

The results were subjected to statistical analysis using single factor variance analysis and the Duncan multiple range test.

\section{RESULTS AND DISCUSSION}

Hetman and Bardo lupin seeds contained somewhat more crude protein (CP) than the seeds of the Wat variety (36 vs. $32 \%$ DM) (Table 3). Lupin Wat contained more ether extract (EE) and crude fibre (CF) in comparison with the other two varieties. The starch content in the lupin seeds was very low (about $0.3 \%$ DM), in agreement with previous studies (Bourdon et al., 1980; Eggum et al., 1993). The highest alkaloid content (TA) was in the Wat variety $(0.106 \%$ DM), i.e. three times more than in Hetman ( $0.035 \%$ DM) and twice that in Bardo 
TABLE 3

Chemical composition of feeds, \% DM

\begin{tabular}{|c|c|c|c|c|c|c|c|}
\hline \multirow[b]{2}{*}{ Ingredients } & \multirow{2}{*}{$\begin{array}{l}\text { Soyabean } \\
\text { meal }\end{array}$} & \multicolumn{4}{|c|}{ Lupins } & \multirow[b]{2}{*}{ Barley } & \multirow[b]{2}{*}{ Wheat } \\
\hline & & Wat & Hetman & Bardo & $\begin{array}{l}\text { dehulled } \\
\text { Bardo }\end{array}$ & & \\
\hline Dry matter & 88.97 & 91.53 & 91.55 & 91.20 & 92.86 & 85.43 & 86.63 \\
\hline Crude ash & 7.18 & 4.27 & 4.43 & 4.70 & 5.09 & 2.75 & 2.27 \\
\hline Crude protein & 51.59 & 31.85 & 36.58 & 36.10 & 43.27 & 13.58 & 12.67 \\
\hline Ether extract & 3.53 & 11.49 & 10.70 & 10.39 & 11.64 & 3.36 & 2.98 \\
\hline Crude fibre & 7.16 & 14.94 & 11.07 & 12.94 & 4.22 & 5.91 & 3.79 \\
\hline NDF & 17.20 & 23.03 & 18.66 & 19.11 & 11.21 & nd & nd \\
\hline $\mathrm{ADF}$ & 8.18 & 19.48 & 14.90 & 15.39 & 5.13 & nd & nd \\
\hline Starch & 0.22 & 0.25 & 0.34 & 0.28 & 0.44 & nd & nd \\
\hline Solube carbohydrates & 13.02 & 11.00 & 10.97 & 12.28 & 13.66 & 3.56 & 4.60 \\
\hline Total alkaloids & - & 0.106 & 0.035 & 0.052 & nd & - & - \\
\hline Gross energy, $\mathrm{MJ} / \mathrm{kg}$ & 20.52 & 21.27 & 21.73 & 21.73 & 21.44 & 18.34 & 17.91 \\
\hline \multicolumn{8}{|l|}{ Amino acids, $\mathrm{g} / 16 \mathrm{~g} \mathrm{~N}$} \\
\hline Thr & 3.88 & 4.05 & 3.90 & 3.72 & 3.63 & 3.50 & 5.15 \\
\hline Cys & 1.37 & 1.83 & 1.81 & 1.80 & 1.82 & 2.37 & 2.53 \\
\hline Met & 1.41 & 0.97 & 0.89 & 0.92 & 0.87 & 1.44 & 1.65 \\
\hline Val & 4.78 & 4.51 & 4.25 & 4.38 & 4.27 & 5.35 & 4.80 \\
\hline Leu & 7.57 & 7.66 & 7.82 & 7.39 & 7.48 & 6.77 & 7.10 \\
\hline Ile & 4.56 & 4.47 & 4.38 & 4.52 & 4.49 & 3.52 & 3.72 \\
\hline Tyr & 3.75 & 4.48 & 4.58 & 4.63 & 4.91 & 3.56 & 3.31 \\
\hline Fen & 5.21 & 3.98 & 4.19 & 4.06 & 4.02 & 5.43 & 4.58 \\
\hline Lys & 5.86 & 5.17 & 4.75 & 4.90 & 4.88 & 3.61 & 3.16 \\
\hline His & 2.41 & 2.37 & 2.13 & 2.19 & 2.05 & 2.34 & 2.38 \\
\hline M EAA ${ }^{1}$ & 90.2 & 87.1 & 83.5 & 84.2 & 82.6 & 86.1 & 85.1 \\
\hline M CS & 64.1 & 44.1 & 40.5 & 41.8 & 39.6 & 55.5 & 48.6 \\
\hline Limiting AA & Met & Met & Met & Met & Met & Lys & Lys \\
\hline
\end{tabular}

${ }^{1}$ M EAAI - modified EAAI; M CS - modified CS - for detailes see Material and Methods

(0.052\% DM). Buraczewska et al. (1993) also found that Wat had a higher TA content than Bardo and Hetman.

Dehulling lupin seeds (var. Bardo) increased their CP content from 36 to $43 \%$ DM (about $20 \%$ ) and decreased NDF content by $41 \%$, ADF and CF by $67 \%$. These changes in the concentration of nutrients after dehulling lupin are comparable to those found by other authors (Brenes et al., 1993; Fernandez and Batterham, 1995; Smulikowska et al., 1995).

The M EAAI of Wat protein was a little higher than that of the Bardo and Hetman varieties (Table 3 ). The M CS index confirms that the first amino acid limiting the value of lupin seed protein for pigs is methionine, which occurs in amounts covering only $40-44 \%$ of the pig's requirements for this amino acid. Both the studies of Gdala et al. (1994) and our results show that it is necessary to 
balance methionine and not total sulphur-containing amino acids in diets of pigs and poultry containing considerable amounts of lupin. Dehulling seeds slightly lowered the content of some essential amino acids, thus of M EAAI and M CS.

In the adaptation period preceding the Experiment 1, the pigs were least willing to eat the diet containing Wat seeds, which contained $0.019 \%$ TA, due to which the weight gains and body weight in this group were lower when the experiment began (Table 4).

TABLE 4

Growth performance, digestibility coefficients and $\mathrm{N}$ balance results (Experiment 1)

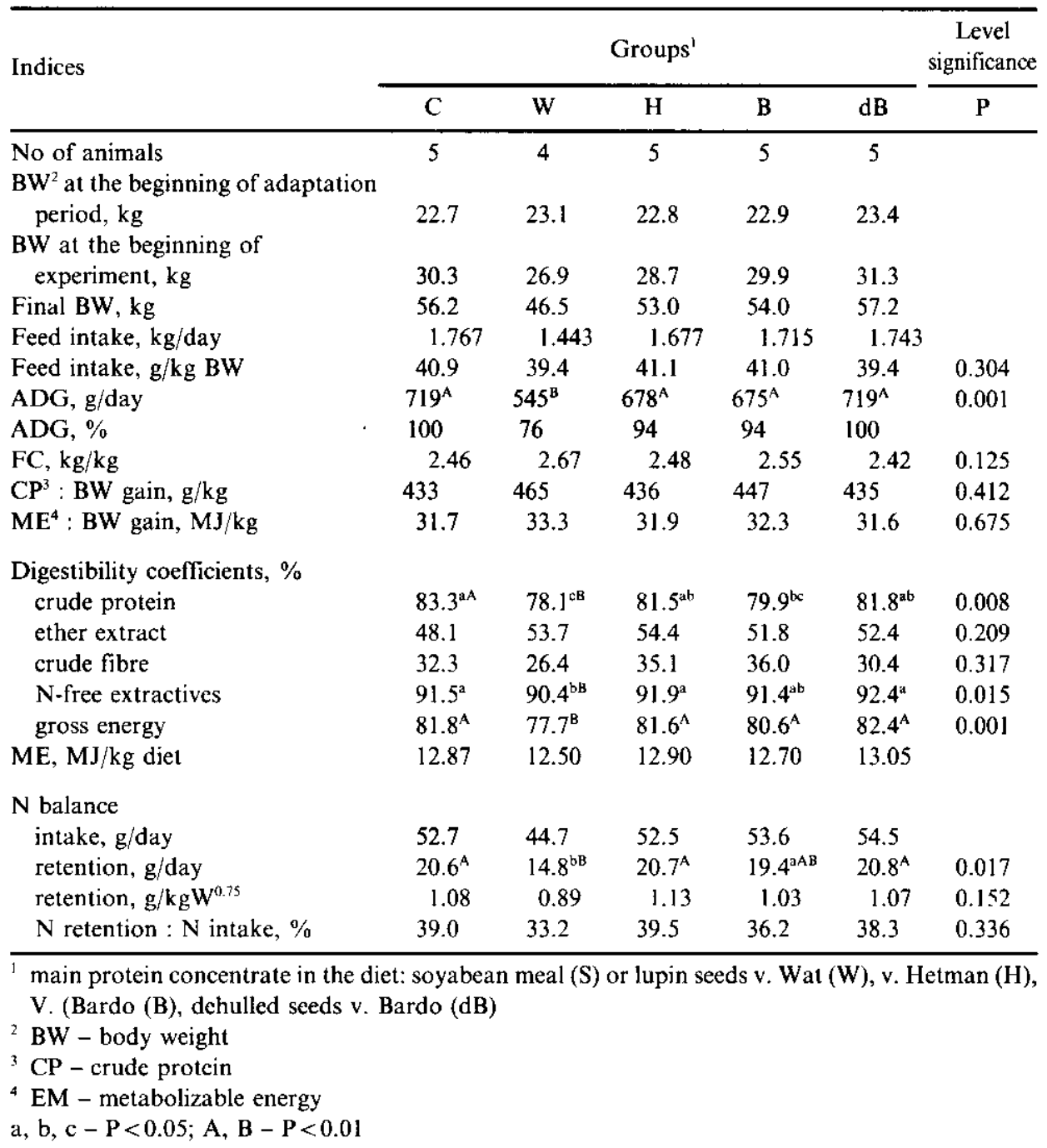


Average daily intake of feeds containing the evaluated varieties of lupin seeds, expressed per $\mathrm{kg}$ body weight (BW), was similar and equaled about $40 \mathrm{~g}$, i.e. $4 \%$ BW. The diet containing the Wat seeds was not eaten readily, and intake was drawn out over a period of a few hours. In groups $\mathrm{H}$ and $\mathrm{B}$ receiving diets with Hetman and Bardo seeds and containing 0.006 and $0.009 \%$ TA, daily weight gains (ADG) were insignificantly $(6 \%)$ lower in comparison with group C. In group $\mathrm{W}$ fed the diet containing Wat seeds and containing $0.019 \% \mathrm{TA}, \mathrm{ADG}$ was significantly lower $(24 \%)$, feed conversion (FC) was insignificantly lower than in group C. The amount of alkaloids introduced into the diet by the $20 \%$ of Wat seeds was found to be too high for the first stage of fattening period. In the experiment by Buraczewska et al. (1993) it was found that young pigs tolerate only up to $0.012 \%$ lupin TA from Wat seeds in their diets, while in this experiment the TA level was higher.

Pigs fed diets containing dehulled lupin Bardo (group dB) had insignificantly higher ADG (6\%) from those fed whole seeds, and the same ADG as in the control group. Although the TA content in the dehulled seeds was not determined, it can be assumed that its content in the $\mathrm{dB}$ and $\mathrm{B}$ groups was similar. Better fattening performance $(P>0.05)$ of group $\mathrm{dB}$ than of group $\mathrm{B}$, equal to that in the control group, can be attributed to the increased nutritional value of the diet due to the decreased fibre content from 5.89 to $3.88 \%$.

Replacing a large part of soyabean meal with lupin Wat decreased the digestibility of all nutrients except fat and fibre. Replacing soyabean meal with Bardo seeds decreased only protein digestibility, while Hetman seeds did not affect the digestibility of any nutrients. The diet containing dehulled lupin was characterized by a higher $(\mathrm{P}>0.05)$ digestibility of protein, $\mathrm{N}$-free extractives and energy, and its energy value was higher by $0.35 \mathrm{MJ} \mathrm{ME} / \mathrm{kg}$ than $\mathrm{ME}$ of the diet containing whole lupin.

Daily nitrogen retention per $\mathrm{kg}$ metabolic body weight did not differ significantly among groups, however in pigs fed the Wat-containing diet it was insignificantly lower. Nitrogen utilization was $36-39 \%$ with the exception of the group fed lupin Wat, in which it was $32 \%(\mathrm{P}>0.05)$.

Nutrients digestibility of white lupin varieties assessed in Experiment 2 did not differ significantly, except energy digestibility (Table 5). The digestibility of all nutrients was high: protein $80.3-83.7 \%$, fat $66.2-71.9 \%$, fibre $43.3-52.5 \%$ and $\mathrm{N}$-free extractives $94-97 \%$. The Hetman variety was characterized by a higher $(\mathrm{P}<0.05)$ energy digestibility $(84.7 \%)$ in comparison with Wat and Bardo $(80.3$ and $80.8 \%$, respectively). These results show that there are only slight differences in the digestibility of protein and energy among the Polish varieties of white lupin.

Average protein digestibility of white lupin was lower than that of yellow lupin ( 82 vs. $86 \%$ ) in the study by Flis (1993), while energy digestibility of white 
TABLE 5

Digestibility coefficients of lupin seed nutrients and nutritive value of seeds (Experiment 2)

\begin{tabular}{|c|c|c|c|c|c|}
\hline \multirow{2}{*}{ Indices } & \multicolumn{3}{|c|}{ Lupin variety } & \multirow{2}{*}{$\begin{array}{l}\text { Dehulled } \\
\text { Bardo }\end{array}$} & \multirow{2}{*}{$\begin{array}{c}\text { Level of } \\
\text { significance } P\end{array}$} \\
\hline & Wat & Hetman & Bardo & & \\
\hline Digestibility coefficients, $\%$ & $\mathrm{n}=4$ & $\mathrm{n}=5$ & $\mathrm{n}=5$ & $\mathrm{n}=5$ & \\
\hline crude protein & 80.3 & 83.7 & 81.7 & 85.8 & 0.249 \\
\hline ether extract & 71.9 & 67.0 & 66.2 & 71.7 & 0.429 \\
\hline crude fibre & 43.3 & 52.5 & 45.8 & 37.6 & 0.475 \\
\hline $\mathrm{N}$-free extractives & 97.1 & 97.1 & 94.0 & 97.1 & 0.499 \\
\hline dry matter & 81.2 & 82.5 & 78.8 & 85.3 & 0.068 \\
\hline energy & $80.3^{\text {bB }}$ & $84.7^{\mathrm{aAB}}$ & $80.8^{\mathrm{bB}}$ & $86.4^{\mathrm{AA}}$ & 0.003 \\
\hline \multicolumn{6}{|l|}{ Nutritive value, in DM } \\
\hline $\mathrm{GE}^{\prime}, \mathrm{MJ} / \mathrm{kg}$ & 21.27 & 21.74 & 21.74 & 21.44 & \\
\hline $\mathrm{DE}^{2}, \mathrm{MJ} / \mathrm{kg}$ & 17.08 & 18.41 & 17.56 & 18.52 & \\
\hline $\mathrm{ME}^{3}, \mathrm{MJ} / \mathrm{kg}$ & 13.99 & 14.57 & 14.06 & 16.02 & \\
\hline $\mathrm{ME} / \mathrm{GE}, \%$ & 65.8 & 67.0 & 64.7 & 74.7 & \\
\hline $\mathrm{DCP}^{4}, \mathrm{~g} / \mathrm{kg}$ & 256 & 306 & 295 & 371 & \\
\hline lysine, $\mathrm{g} / \mathrm{kg}$ & 16.8 & 17.4 & 17.7 & 21.1 & \\
\hline crude fibre, $\mathrm{g} / \mathrm{kg}$ & 149 & 111 & 129 & 42 & \\
\hline
\end{tabular}

' gross energy

${ }^{2}$ digestible energy

${ }^{3}$ metabolizable energy

${ }^{4}$ digestible crude protein

$\mathrm{a}, \mathrm{b}-\mathrm{P}<0.05 ; \mathrm{A}, \mathrm{B}-\mathrm{P}<0.01$

lupin (average $82 \%$ ) was higher than in yellow lupin (average $72 \%$; Flis, 1993). The higher digestibility of energy in white than in yellow lupin may result from its higher fat and lower fibre contents. In experiments on rats Eggum et al. (1993) showed that the energy digestibility of white lupin was higher than of a narrow-leafed variety.

Dehulling seeds had a greater effect on the digestibility of energy than of protein. The increase of protein digestibility (from 81.7 to $85.8 \%$ ) was not significant, while the rise in energy digestibility (from 80.8 to $86.4 \%$ ) was highly significant. In studies on young pigs Fernandez and Batterham (1995) also found a significant increase in energy digestibility of lupin (narrow-leafed) as the result of dehulling.

The tested lupin varieties contained from 17.1 to $18.4 \mathrm{MJ} \mathrm{DE}$, from 14.0 to 14.6 MJ ME and 256 to $306 \mathrm{~g} \mathrm{DCP}$ per $\mathrm{kg}$ DM. The Hetman variety had the greatest nutritional value. In comparison with whole seeds, the dehulled seeds contained (in DM) more DE (18.5 vs. $17.6 \mathrm{MJ}), \mathrm{ME}(16.0$ vs. $14.1 \mathrm{MJ})$, DCP (371 vs. $295 \mathrm{~g}$ ) and lysine (21.1 vs. $17.7 \mathrm{~g}$ ) and less CF (42 vs. $129 \mathrm{~g} / \mathrm{kg} \mathrm{DM})$. The higher nutritional value of dehulled seeds was due to the increased concentration of all 
(except fibre) components and higher digestibility of nutrients of dehulled seeds. Fernandez and Batterham (1995) had also found that dehulling improved the nutritional value of lupin seeds for pigs, and Brenes et al. (1993) and Smulikowska et al. (1995) observed a similar effect on nutritional value for poultry.

\section{CONCLUSIONS}

Of the three compared Polish low-alkaloid varieties of white lupin, the higher nutritional value for growing pigs was found in the newer varieties, Hetman and Bardo, than in the older variety, Wat, mainly due to the its lower alkaloid content. When the seeds were added in an amount of $20 \%$ to the diets fed to the pigs in the range of $\mathrm{BW} 20$ to $55 \mathrm{~kg}$, only the Wat variety caused a significant deterioration of performance. Dehulling white lupin seeds increases the crude protein content (by $20 \%$ ), decreases the crude fibre content (by $67 \%$ ) and increases energy digestibility. In comparison with whole seeds, dehulled seeds contain more metabolizable energy (by 14\%) and digestible protein (by $25 \%$ ) and when used in iso-protein amounts allow for slightly better daily weight gain of pigs.

\section{REFERENCES}

Bourdon D., Perez J.M., Calmes R., 1980. Le lupin (Lupinus albis L.) dans l'alimentation du porc - valeur énergétique et azotée et conditions d'utilisation. Journes Rech. Porcine en France, 12, 245-264

Brand T.S., Olckers R.C., van der Merwe J.P., 1995. Evaluation of faba beans (Vicia faba cv. Fiord) and sweet lupins (Lupinus albus cv. Kiev) as protein sources for growing pigs. S. Afr. J. Anim. Sci. $25,31-35$

Brenes A., Marquardt R.R., Gunter W., Rotter B.A., 1993. Effect of enzyme suplementation on the nutritional value of raw, autoclaved, and dehulled lupin (Lupinus albus) in chicken diets. Poultry Sci. $72,2281-2293$

Buraczewska L., Pastuszewska B., Smulikowska S., Wasilewko J., 1993. Response of pigs, rats and chickens to dietary level of alkaloids of different lupin species. In: A.F.B. van der Poel. J. Huisman, H.S. Saini (Editors). Proceedings of the 2nd International Workshop and Antinutritional Factors (ANFs) in Legume Seeds. Wagenningen Pers, Wagenningen, pp. $371-376$

Eggum B.O., Tomes G., Beames R.M., Datta F.U., 1993. Protein and energy evaluation with rats of seed from 11 lupin cultivars. Anim. Feed Sci. Technol. 43, 109-119

Fernandez J.A., Batterham E.S., 1995. The nutritive value of lupin-seed and dehulled lupin-seed meals as protein sources for growing pigs as cvaluated by different techniques. Anim. Fecd Sci. Technol. 53, 279-296

Flis M., 1993. Nutritive value for pigs the sceds of new faba bean and yellow lupin varictics (in Polish). Acta Acad Agric. Tech. Olst., Zoot. 38, Suppl. A, I-48 
Flis M., Lewicki Cz., Tywończuk J., Meller Z., 1989. Evaluation of nutritive value of new varieties of different legume seeds in feeding of fatteners. II. Production effects and after-slaughter carcass quality (in Polish). Acta Acad. Agric. Tech. Olst., Zoot. 32, 85-97

Fuchs B., Fritz Z., Orda J., Krzywiecki S., 1983. Comparision of feeding value of faba bean, lupin and pea seeds in fattening pigs (in Polish). Zesz. Nauk. AR Wrocław 140, Zoot. 25, 103-111

Gdala J., Buraczewska L., Wasilewko J., 1994. Ileal digestibility of amino acids and nutritive value of protein of yellow lupin (Lupinus luteus) seeds for growing pigs (in Polish). Proceedings of Conference Recent Advances in Swine Nutrition, Jabłonna (Poland), pp. 77-81

Gdala J., Jansman A.J.M., van Leeuwen P., Huisman J., Verstegen M.W.A., 1996. Lupins (L. luteus, L. albus. L. angustfolius) as a protein source for young pigs. Anim. Feed Sci. Technol. 62, 239-249

Hoffmann L., Schiemann R., 1980. Von der Kalorie zum Joule : Neue Grössenbeziehungen bei Messungen des Energieumsatzes und bei der Berechnung von Kennzahlen der energetischen Futterbewertung. Arch. Tierernähr. 30, 733-742

Jacórzyński B., 1986. Oligosaccharides as a factor limiting feeding value of leguminous seeds (in Polish). Institute of Food and Feeding (Editor), Warszawa, Publ. No. 43

Kepller D., Decker K., 1970. Glykogen Bestimmung mit Amyloglucosidase. In : H. U. Bergmeyer (Editor). Methoden der enzymatischen Analyse. Band II. Akademic Verlag, Berlin, pp. 1089-1094

King R.H., 1981. Lupin-seed meal (Lupinus albus cv. Hamburg) as a source of protein for growing pigs. Anim. Feed Sci. Technol. 6, 285-296

Müller H.L., Kirchgessner M., 1983. Energetische Verwertung von Cellulose beim Schwein. Z. Tierphysiol. Tierernähr. Futtermittelk. 49, 127-133

Nutrient Requirements of Pigs. Nutritive Value of Feeds (in Polish), 1993. Editor: The Kielanowski Institute of Animal Physiolgy and Nutrition, Jabłonna (Poland)

Smulikowska S., Wasilewko J., Mieczkowska A., 1995. A note on the chemical composition of the cotyledons and seed coat of three species of sweet lupin. J. Anim. Feed Sci. 4, 69-76

Van Soest P.J., Wine R.H., 1967. Use of detergents in the analysis of fibrous feeds. IV. Determination of plant cell wall constituents. J. Assoc. Off Agric. Chem. 50, 50-55

Wang T.C., Fuller M.F., 1990. The effect of the plane of nutrition on the optimum dietary amino acid pattern for growing pigs. Anim. Prod. 50, 155-164

Wysocka W., Brukwicki T., Jałoszyński R., Hofman K., 1989. A new and efficient method of extraction of alkaloids from lupin seeds. Lupin Lett. No. 13, 59-65

Zduńczyk Z., Juśkiewicz J., Flis M., Amarowicz R., Krefft B., 1996. The chemical composition and nutritive value of low-alkaloid varietes of white lupin. 1. Seed, cotyledon and seed coat characteristics. J. Anim. Feed Sci. 5, 63-72

Zettl von A., Lettner F., Wetscherek W., 1995. Einsatz von weisser Süsslupine (Lupinus albus var. Amiga) in der Schweinemast. Die Bodenkultur, 46, 165-167

\section{STRESZCZENIE}

Wpływ odmiany i odłuszczenia na wartość odżywczą nasion łubinu białego w żywieniu rosnących świń

W 36 dniowym doświadczeniu wzrostowym (Dośw. 1) na 24 wieprzkach (30-56 kg m.c.) określono wartość odżywczą trzech polskich odmian łubinu białego: całych nasion starszej odmiany Wat i nowszej odmiany Hetman oraz całych lub odłuszczonych nasion najnowszej odmiany Bardo. 
Wprowadzając $20 \%$ całych nasion lub $16,5 \%$ odłuszczonych nasion, zmniejszono zawartość śruty sojowej z $19 \%$ w mieszance kontrolnej do $6-9 \%$ w mieszankach doświadczalnych.

W porównaniu z grupą kontrolną świnie otrzymujące łubin Wat $(0,106 \%$ alkaloidów w s.m.) mialy istotnie gorsze przyrosty dobowe i wykorzystanie paszy, natomiast otrzymujące hubin Hetman lub Bardo (odpowiednio 0,035 i 0,052\% alkaloidów) miały tylko nieistotnie gorsze wskaźniki tuczu. U świń żywionych odłuszczonymi nasionami wyniki tuczu były takie same jak w grupie kontrolnej.

W drugim doświadczeniu (Dośw. 2) oznaczono strawność skladników pokarmowych nasion trzech odmian łubinu oraz nasion odłuszczonych odm. Bardo metodą różnicową. Nie stwierdzono istotnych różnic w strawności białka ogólnego, ckstraktu eterowego, włókna surowego i związków bezazotowych wyciągowych ocenianych odmian lubinu. Łubin Hetman wyróżniał się najwiçkszą strawnością energii. Odłuszczenie nasion wpłynęło na wzrost strawności energii z 80,8 do $86,4 \%$ $(\mathrm{P}<0,01)$. Nasiona odluszczone zawierały w s.m. więcej energii metaboliczncj $(16,0 \mathrm{vs} .14,1 \mathrm{MJ} / \mathrm{kg})$ i strawnego białka (371 vs. $295 \mathrm{~g} / \mathrm{kg}$ ), zaś mniej włókna surowego (42 vs. $129 \mathrm{~g} / \mathrm{kg}$ ) niż nasiona całe. 